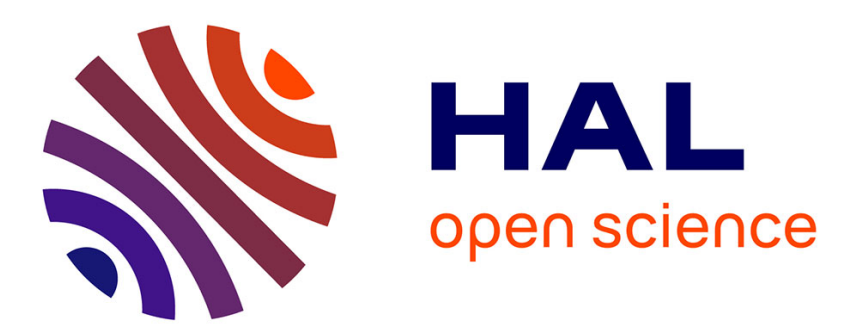

\title{
Microbial diversity in a pyrite-rich tailings impoundment (Carnoulès, France)
}

O. Bruneel, Robert Duran, K. Koffi, C. Casiot, A. Fourçans, F. Elbaz-Poulichet, J.-C. Personné

\section{- To cite this version:}

O. Bruneel, Robert Duran, K. Koffi, C. Casiot, A. Fourçans, et al.. Microbial diversity in a pyriterich tailings impoundment (Carnoulès, France). Geomicrobiology Journal, 2005, 22 (5), pp.249-257. 10.1080/01490450590947805 . hal-01841790

\section{HAL Id: hal-01841790 \\ https://hal.science/hal-01841790}

Submitted on 19 Jan 2022

HAL is a multi-disciplinary open access archive for the deposit and dissemination of scientific research documents, whether they are published or not. The documents may come from teaching and research institutions in France or abroad, or from public or private research centers.
L'archive ouverte pluridisciplinaire HAL, est destinée au dépôt et à la diffusion de documents scientifiques de niveau recherche, publiés ou non, émanant des établissements d'enseignement et de recherche français ou étrangers, des laboratoires publics ou privés. 


\title{
Microbial Diversity in a Pyrite-Rich Tailings Impoundment (Carnoulès, France)
}

\author{
Odile Bruneel \\ Laboratoire Hydrosciences Montpellier, Université Montpellier 2, Montpellier cedex 05, France

\begin{abstract}
Robert Duran
Laboratoire d'Ecologie Moléculaire-Microbiologie, EA 3525, Université de Pau et des Pays de l'Adour, Pau cedex, France
\end{abstract}

\author{
Kouadio Koffi and Corinne Casiot \\ Laboratoire Hydrosciences Montpellier, UMR 5569, Université Montpellier 2, Montpellier cedex 05, \\ France
}

\author{
Aude Fourçans \\ Laboratoire d'Ecologie Moléculaire-Microbiologie, EA 3525, Université de Pau et des Pays de l'Adour, \\ Pau cedex, France
}

Françoise Elbaz-Poulichet and Jean-Christian Personné

Laboratoire Hydrosciences Montpellier, UMR 5569, Université Montpellier 2, Montpellier cedex 05, France

The microbial communities have been investigated in the subsurface waters of the Carnoulès pyrite-rich tailings impoundment (France) for two hydrological situations characterized by the presence of oxygenated waters during winter and suboxic conditions in early autumn. In these acidic waters (2-5) characterized by elevated concentrations of $\mathrm{Fe}\left(1608-3354 \mathrm{mg} \cdot \mathrm{I}^{-1}\right)$, As $\left(130-434 \mathrm{mg} \cdot \mathrm{I}^{-1}\right)$ and sulfates $\left(5796-14318 \mathrm{mg} \cdot \mathrm{I}^{-1}\right)$ and variable dissolved oxygen content, the cultivable bacteria found in these system are Thiomonas and Acidithiobacillus ferrooxidans. Molecular methods, TerminalRestriction Fragment Length Polymorphism (T-RFLP), and 16S rRNA encoding gene library analysis indicate low diversity. The environment is dominated by only a few types of microorganisms, with 70-80\% of the whole bacterial population assigned to two or three Terminal-Restriction Fragments (T-RFs). Most of these organisms are uncultured, newly described, or recently associated with acid mine drainage. Modifications of the community structure are observed as a function of the sampling period and seem to be related to the aqueous chemistry of the tailings water. At low Dissolved Oxygen $\left(\mathrm{DO}=1 \mathrm{mg} \cdot \mathrm{I}^{-1}\right)$ concentrations and moderately acidic conditions $(\mathrm{pH}=5.7)$, the dominant organisms are related to

This study was financed by the Programmes Environment Vie et Société and GEOMEX (CNRS) and the ACI-Ecologie Quantitative (French Ministry of Research).

Address correspondence to Odile Bruneel, Laboratoire Hydrosciences Montpellier, UMR 5569, Université Montpellier 2, Place E, Bataillon, Case MSE, 34095 Montpellier cedex 05, France. E-mail: obruneel@msem.univ-montp2.fr the uncultured clone BA31 affiliated with Desulfosarcina variabilis, a sulfate-reducing bacteria (SRB), Acidithiobacillus ferrooxidans and the uncultured clone BVB20, closely related to Thiobacillus. At high $\left(12 \mathrm{mg} \cdot \mathrm{I}^{-1}\right)$ DO concentrations and low $(<2) \mathrm{pH}$ values, the microbial diversity is less important and $65 \%$ of the population is assigned to the uncultured bacterium clone AS6 related to Desulfosarcina variabilis.

Keywords microbial diversity, arsenic, mine tailings, acid mine drainage, terminal restriction fragment length polymorphism

\section{INTRODUCTION}

The mining of metallic sulfide ores produces pyrite-rich mine wastes which generate Acid Mine Drainage (AMD) when exposed to oxygenated water. The formation of AMD, which contains high concentrations of sulfates, iron, arsenic, and metals $(\mathrm{Pb}, \mathrm{Cd}, \mathrm{Zn})$, depends on the availability of oxygen and $\mathrm{Fe}(\mathrm{III})$, both acting as oxidants (Langmuir 1997). The reaction is mediated by acidophilic iron-oxidizing microorganisms (Silverman and Ehrlich 1964) which play a major role in maintaining the $\mathrm{Fe}(\mathrm{III})$ availability, especially at low $\mathrm{pH}$, where the abiotic oxidation rate of $\mathrm{Fe}$ (II) by dissolved oxygen (DO) is slow (Edwards et al. 1999). In spite of their importance in the generation of AMD, the populations of naturally occurring prokariotic microorganisms in AMD are poorly known. Until a decade ago, relatively few acidophiles were recognized, 
and enrichment/cultivation based studies have probably overestimated the importance and the role of Acidithiobacillus ("A.") ferrooxidans and A. thiooxidans in AMD.

The use of molecular-based analysis has highlighted the significant variability of microbial diversity in AMD (Johnson and Hallberg 2003). To date, bacteria from several divisions (proteobacteria, nitrospira, firmicutes, actinobacteria, and acidobacteria) have been detected in AMD environments (Baker and Banfield 2003). Among these organisms, the most extensively studied group (but possibly the least relevant under AMDgenerating conditions) are the proteobacteria, specifically Acidithiobacillus spp. (Kelly and Wood 2000) and Thiobacillus spp.

The objective of this study was to characterize the microbial communities structures in As-rich AMD and their variations as a function of dissolved oxygen concentration and $\mathrm{pH}$. The study was carried out in the aquifer of the tailings stock of the Carnoulès mine (France). The water is acidic $(\mathrm{pH}=2-5)$ and can contain occasionally up to $12000 \mathrm{mg} \cdot \mathrm{1}^{-1}$ of As (Leblanc et al. 2002). The water chemistry and especially its oxygen content drastically varies as a function of hydrological conditions (Koffi et al. 2003). The variations of the community structure for contrasting dissolved oxygen concentrations were investigated using two complementary molecular methods (T-RFLP, and 16S rRNA encoding gene library analysis) and usual culturing techniques (isolation, counting, and identification of culturable bacteria).

\section{MATERIALS AND METHODS}

\section{Site Description}

The $\mathrm{Pb}-\mathrm{Zn}$ Carnoulès mine is located in southern France (Figure 1). The ore extraction, which stopped in 1962 has left 1.5 Mt of wastes containing quartz (75 wt.\%), and arsenic-rich pyrite (5-15 wt.\%) (Casiot et al. 2003). The mean annual rainfall is $1320 \mathrm{~mm}$ of rain with a distribution typical of the Mediterranean climate characterized by long drought periods and heavy rains occurring mainly in autumn and spring. The aquifer is not fed by the vertical percolation of rainwater through the tailings, but rather originates from former natural springs that were buried under the tailings (Koffi et al. 2003). The water table occurs at 1 to $10 \mathrm{~m}$ below the surface of the tailings stock according to season and location. With the exception of the temperature, which is almost constant at about $15^{\circ} \mathrm{C}$, the other physicochemical parameters of ground water change in relation to the hydrological conditions as shown by Koffi et al. (2003) and Casiot et al. (2003). The highest DO concentrations (up to $12 \mathrm{mg} \cdot \mathrm{l}^{-1}$ ) are observed during the rise of the water table, the water is saturated with regards to oxygen. When the water level stabilizes, the DO concentrations drop suddenly to microaerobic conditions (1 $\left.\mathrm{mg} \cdot \mathrm{l}^{-1}\right)$. The $\mathrm{pH}$ varies inversely to DO with strongly acidic values $(\leq 1.8)$ at high DO concentrations. It increases to $5-6$ at low DO values.

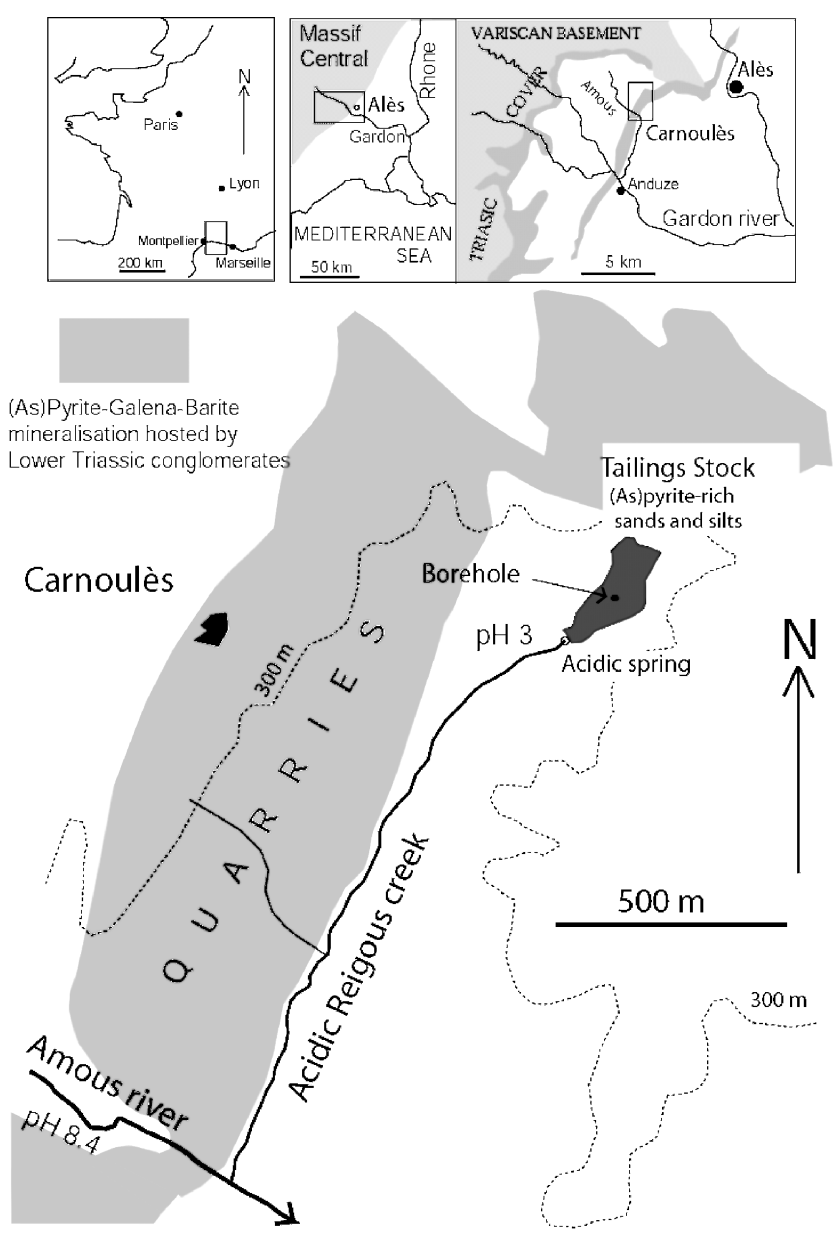

FIG. 1. Location and map of the Carnoulès mining site.

\section{Sampling Procedure and Physicochemical Determinations In Situ}

Water samples were collected from a borehole located in the center of the tailing where the water chemistry varies in a particularly large range according to hydrology (Koffi et al. 2003). Samples for usual cultural techniques were collected in the end of 2001 until the beginning of 2003. The corresponding $\mathrm{pH}$ are presented in Figure 7. Sampling for molecular microbial determinations was carried out in October 2002 and January 2003. The two periods correspond to contrasting water chemistry as shown in Table 1. At each time, $200 \mathrm{ml}$ of water were filtered through a $0.22 \mu \mathrm{m}$ sterile Nucleopore filter, introduced into a tube, frozen in liquid nitrogen, and stored at $-20^{\circ} \mathrm{C}$ until further analysis. Samples for counting of viable bacteria and for bacterial isolation were collected in sterile vials and processed for microbiological studies within $5 \mathrm{~h}$ of sampling.

\section{Culture Media and Bacterial Identification}

Two kinds of solid media were used for counting of viable bacteria from the tailings. Heterotrophic and nonobligatory acidophilic bacteria in the samples were cultured on a solid 
TABLE 1

Physicochemical characteristics of the water in the tailings during the sampling in October 2002 and January 2003

\begin{tabular}{lccccccccr}
\hline Sampling period & $\mathrm{pH}$ & $\begin{array}{c}\mathrm{T} \\
\left({ }^{\circ} \mathrm{C}\right)\end{array}$ & $\mathrm{Eh}$ & $\begin{array}{c}\mathrm{Do} \\
\left(\mathrm{mg} \cdot \mathrm{l}^{-1}\right)\end{array}$ & $\begin{array}{c}\mathrm{As}(\mathrm{III}) \\
\left(\mathrm{mg} \cdot \mathrm{l}^{-1}\right)\end{array}$ & $\begin{array}{c}\mathrm{As}(\mathrm{V}) \\
\left(\mathrm{mg} \cdot \mathrm{l}^{-1}\right)\end{array}$ & $\begin{array}{c}\mathrm{Fe} \mathrm{T} \\
\left(\mathrm{mg} \cdot \mathrm{l}^{-1}\right)\end{array}$ & $\begin{array}{c}\mathrm{Fe}(\mathrm{II}) \\
\left(\mathrm{mg} \cdot \mathrm{l}^{-1}\right)\end{array}$ & $\begin{array}{r}\mathrm{SO} 4^{2-} \\
\left(\mathrm{mg} \cdot 1^{-1}\right)\end{array}$ \\
\hline October & 5.7 & 13.5 & 20 & 1 & 104 & 24 & 1667 & 1608 & 5796 \\
January & 1.88 & 13.3 & 257 & 12 & 413 & 21 & 3468 & 3354 & 14318 \\
\hline
\end{tabular}

medium R2A (pH 7.0) (Difco laboratory) and medium 100:10 (pH 3.5) (Schrader and Holmes 1988), developed for the growth of acidophilic lithotrophic bacteria (containing a mixture of both ferrous iron and thiosulfate as available energy sources). $0.1 \mathrm{ml}$ of sample was spread on the media (three replicates) and incubated 21 days at $30^{\circ} \mathrm{C}$. Each colony type was identified by $16 \mathrm{~S}$ rDNA sequencing (Bruneel et al. 2003).

\section{Bacterial Enumeration}

The number of Colony Forming Units (CFU) of each type was counted on the three replicates. The total bacterial number in the tailings samples was estimated by epifluorescent microscopy after DAPI staining.

\section{DNA Isolation}

Genomic DNA was extracted from filtered water using the UltraClean Soil DNA Isolation Kit according to the recommendation of the manufacturer (MoBio Laboratories Inc., USA). All extracted genomic DNA samples were stored at $-20^{\circ} \mathrm{C}$ until further processing.

\section{T-RFLP Analysis}

Primers 8F and 1489R (Lane 1991; Weisburg et al. 1991) were used for T-RFLP analysis to assess the bacterial community structures. Forward $(8 \mathrm{~F})$ and reverse $(1489 \mathrm{R})$ primers were fluorescently labeled with TET and HEX (E.S.G.S. Cybergene group, France), respectively. The PCR amplification mixture contained $12.5 \mu 1$ Hot Start Taq polymerase master mix (Qiagen, Netherlands), $0.5 \mu \mathrm{l}$ of each primer $(20 \mu \mathrm{M})$ and $10 \mathrm{ng}$ of DNA template. A final volume of $50 \mu \mathrm{l}$ was adjusted with distilled water. 16S rDNA gene amplification reactions were cycled in a PTC200 thermocycler (MJ Research, USA) with a hot start step at $94^{\circ} \mathrm{C}$ for $15 \mathrm{~min}$, followed by 35 cycles of $94^{\circ} \mathrm{C}$ for $1 \mathrm{~min}, 52^{\circ} \mathrm{C}$ for $1.5 \mathrm{~min}$, and $72^{\circ} \mathrm{C}$ for $1 \mathrm{~min}$, with a final extension step at $72^{\circ} \mathrm{C}$ for $10 \mathrm{~min}$. The amount of PCR product was determined by comparison to known concentrations by the "dots method" (Smartlader, Eurogentec, Belgium) after migration on agarose gel. PCR products were purified with the GFX PCR DNA purification kit (Amersham-Pharmacia, U.K.).

Purified PCR products (600 to $700 \mathrm{ng}$ ) were digested with 12 units of enzyme HaeIII or HinfI (New England Biolabs, USA). The length of T-RFs from the digested PCR products was determined by capillary electrophoresis on ABI prism 310, (Applied Biosystems, USA). About $50 \mathrm{ng}$ of the digested DNA from each sample was mixed with $10 \mu \mathrm{l}$ of deionized formamide and $0.25 \mu \mathrm{l}$ of TAMRA size standard and then denatured at $94^{\circ} \mathrm{C}$ for 2 min and immediately chilled on ice prior to electrophoresis. After an injection step of $10 \mathrm{~s}$, electrophoresis was carried out for up to $30 \mathrm{~min}$ applying a voltage of $15 \mathrm{KV}$. T-RFLP profiles were performed using GeneScan software (ABI).

Dominant Operational Taxonomic Units (OTUs) represent T-RFs whose fluorescence was higher than 100 Fluorescence Units for at least one sample. Predictive digestions were made on the RDP web site 〈http://rdp.cme.msu.edu/html/index.html using the T-RFLP Analysis Program (TAP).

\section{Cloning and Restriction Analysis}

To further characterize the bacterial populations inhabiting the borehole in each sampling period, the bacterial diversity was analyzed by cloning PCR amplified 16S rRNA encoding genes, obtaining a clone library for each sampling period. Sixty clones from each library were analyzed according to their RFLP patterns (HaeIII and HinfI digestion). The clones were divided into four dominant groups for October and three groups for January.

Bacterial 16S rRNA encoding gene (16S rDNA) was amplified with unlabelled $8 \mathrm{~F}$ and $1489 \mathrm{R}$ primers. These $\mathrm{PCR}$ products were cloned in E. coli TOP 10 using the pCR2.1 Topo TA cloning kit (Invitrogen, Inc.). Cloned 16S rDNA fragments were amplified using the primers TOP1 and TOP2 located on the vector, and then digested with the enzymes HaeIII or HinfI. Restriction profiles were analyzed on $2.5 \%$ agarose gel electrophoresis (small fragments resolution agarose; QA agarose, QBiogène, Inc.).

\section{$16 S$ rDNA Sequencing}

Partial sequences of the 16S rDNA gene (from 8 to 336 according to $E$. coli numbering) were determined by the dideoxy nucleotide chain-termination method using the BigDye cycle sequencing kit (Applied Biosystems) on an ABI PRISM 310 Genetic analyzer (Applied Biosystems). DNA sequence analyses were performed via the infobiogen server $\langle\mathrm{http}: / / \mathrm{www}$. infobiogen.fr $\rangle$ by using the FASTA, BLAST, ALIGNN, and CLUSTALW programs (Altschul et al. 1990; Baneyx 1999; Felsenstein 1993; Thompson et al. 1994). Phylogenetic trees were constructed by using the PHYLIP computer package (Felsenstein 1993). The confidence level of the phylogenetic tree topology was evaluated by performing 100 bootstrap replications with the programs SEQBOOK and CONSENSE. 


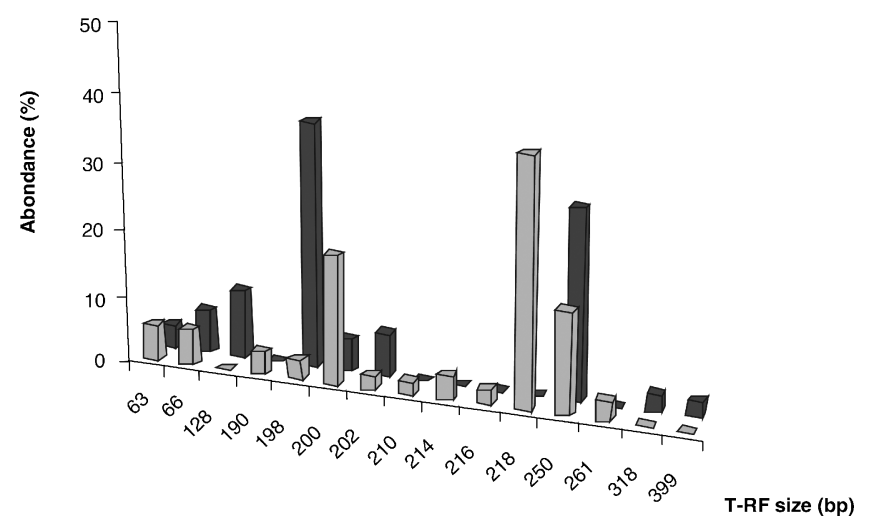

FIG. 2. Comparison of bacterial community T-RFLP fingerprints in tailings water at the Carnoulès Mine. October $(\square)$ and January ( $\square)$ samples.

\section{RESULTS}

\section{Communities Structures}

The results of T-RFLP analysis are presented in Figure 2. The number and distribution of major OTUs, indicates a generally low bacterial diversity (12 OTUs in October and 9 in January). The bacterial populations characterized by OTUs $63,66,198$, 200,202 , and $250 \mathrm{bp}$ are found in both sampling periods but the importance of each OTU vary greatly between the 2 sampling periods. Differences occur for other bacterial population, OTUs $190,210,214,216,218$, and $261 \mathrm{bp}$ are found only in October whereas the OTUs 128, 318, and 399 bp are present only in January.

\section{Composition of Bacterial Communities}

The results are presented in Table 2. Most of the clone sequences are related to sequences already found in AMD,

TABLE 2

Bacterial clones from each sampling period with closest match organism or clone name, percent similarity, phylogenetic group, closest relative and postulated metabolism and percent number of each group compared to the total number of clones.

\begin{tabular}{|c|c|c|c|c|c|}
\hline Clone & $\begin{array}{l}\text { Closest match organism } \\
\text { or clone name } \\
\text { and accession number }\end{array}$ & $\begin{array}{c}\% \\
\text { similarity }\end{array}$ & $\begin{array}{l}\text { Phylogenetic } \\
\text { group }\end{array}$ & $\begin{array}{l}\text { Closest relative and postulated } \\
\text { metabolism }\end{array}$ & $\begin{array}{c}\% \\
\text { number } \\
\text { of clone }\end{array}$ \\
\hline S5Oct30 & Uncultured bacterium BA31 & 93 & $\delta$-proteobacteria & Desulfosarcina variabilis-Sulfate/iron & 27 \\
\hline S5Oct38 & (AF543508) & 94 & & reduction & \\
\hline S5Oct 42 & & 87 & & & \\
\hline S5Oct70 & & 94 & & & \\
\hline S5Oct51 & & 95 & & & \\
\hline S5Oct 80 & & 94 & & & \\
\hline S5Oct73 & & 94 & & & \\
\hline S5Oct11 & & 95 & & & \\
\hline S5Oct27 & $\begin{array}{l}\text { Acidithiobacillus ferrooxidans } \\
\text { SS6(AJ278721) }\end{array}$ & 99 & $\gamma$-proteobacteria & $\begin{array}{l}\text { Acidithiobacillus ferrooxidans-Sulfide/iron } \\
\text { oxidation and iron reduction }\end{array}$ & 14 \\
\hline S5Oct75 & $\begin{array}{l}\text { Uncultured bacterium RA13C4 } \\
\text { (AF407404) }\end{array}$ & 99 & & & \\
\hline S5Oct74 & Uncultured Banisveld landfill & 98 & $\beta$-proteobacteria & Thiobacillus_-Sulfide/iron oxidation & 12 \\
\hline S5Oct85 & bacterium BVB20 (AY013650) & 99 & & & \\
\hline S5Oct17 & $\begin{array}{l}\text { Unknown Actinomycete MC87 } \\
\text { (X68455) }\end{array}$ & 87 & Actinobacteria & Acidimicrobium-Sulfide/iron oxidation & 2 \\
\hline S5Jan 41 & Uncultured bacterium AS6 & 98 & $\delta$-proteobacteria & Desulfosarcina variabilis-Sulfate/iron & 65 \\
\hline S5Jan43 & (AF543496) & 98 & & reduction & \\
\hline S5Jan59 & & 98 & & & \\
\hline S5Jan36 & & 95 & & & \\
\hline S5Jan20 & $\begin{array}{l}\text { Uncultured Acidithiobacillus } \\
\text { ferrooxidans KF/GS-JG36-22 } \\
\text { (AJ295655) }\end{array}$ & 99 & $\gamma$-proteobacteria & $\begin{array}{l}\text { Acidithiobacillus ferrooxidans-Sulfide/iron } \\
\text { oxidation and iron reduction }\end{array}$ & 8 \\
\hline S5Jan27 & $\begin{array}{l}\text { Acidithiobacillus ferrooxidans } \\
\text { strain SS6 (AJ278721) }\end{array}$ & 99 & & & \\
\hline S5Jan 28 & Uncultured Sulfobacillus sp. & 93 & Firmicutes & Sulfobacillus-Sulfide/iron oxidation and iron & 8 \\
\hline S5Jan35 & P3-5(AF460985) & 94 & & reduction & \\
\hline
\end{tabular}




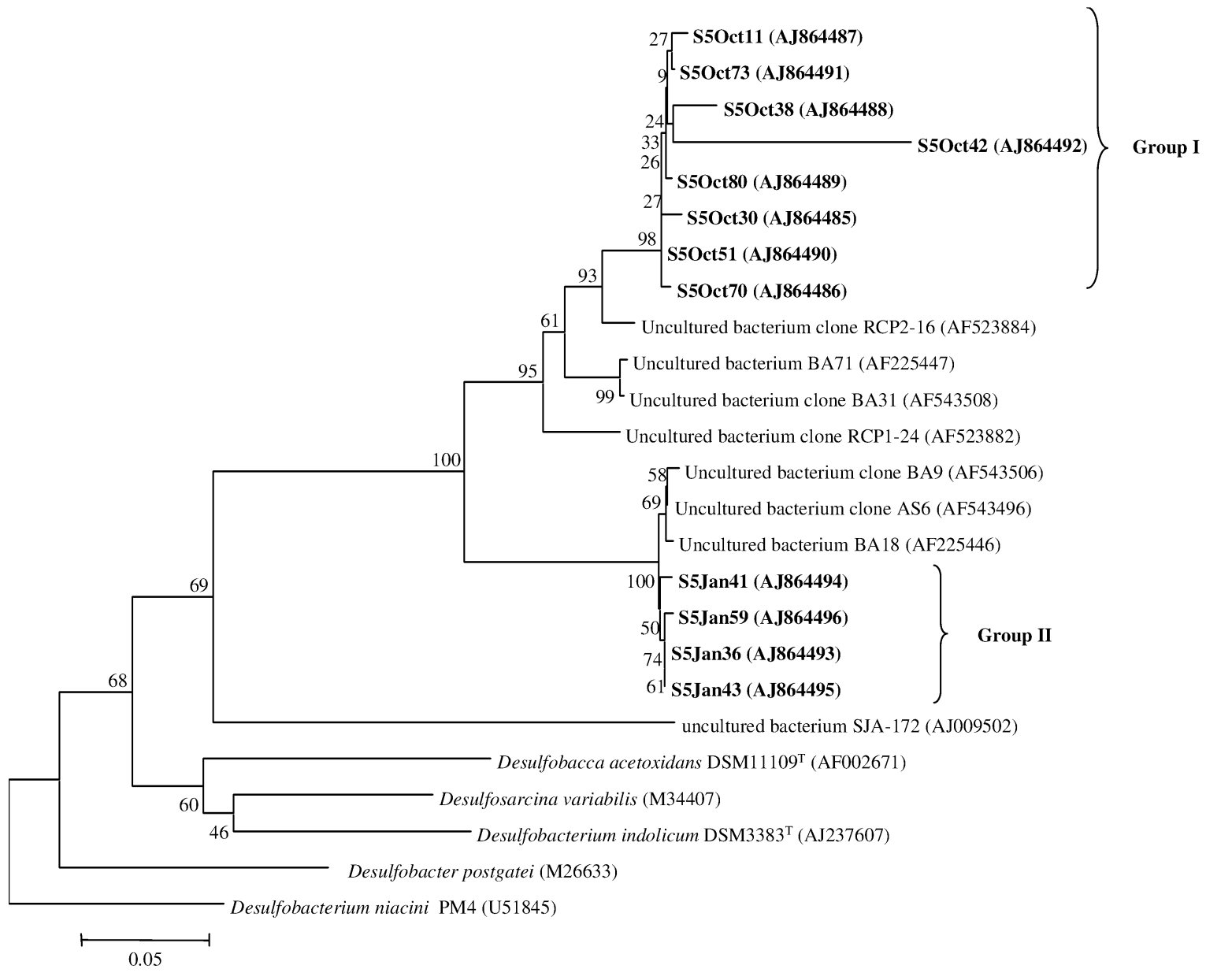

FIG. 3. Phylogenetic analysis of $16 \mathrm{~S}$ rRNA encoding gene sequences affiliated with the Desulfobacter division in tailings water at the Carnoulès mine (France). Clone names in bold correspond to sequences found in October (Oct) and January (Jan).

indicating that the clone libraries have not been contaminated. In accordance with the T-RFLP results, this analysis indicates major differences in the bacterial populations between the sampling periods even if it's the same functional group. About $90 \%$ of the sequences are closely related to sequences of uncultured bacterial clones, and only $10 \%$ to $16 \mathrm{~S}$ rDNA sequences of identified species. The most abundant sequence type, representing $27 \%$ of the clones in October and $65 \%$ in January, are positioned within the delta subdivision of the Proteobacteria (Table 2, Figure 3). Clones from October form a distinctive group (Group I), showing about $94 \%$ similarity with the sequence of the clone BA31 found in AMD at Iron Mountain (unpublished data, AF543508) and about $85 \%$ similarity with the sequences from clones found in January (Group II). The Group II sequences are closely related (99\%) to the sequence of the clone AS6, also found in AMD at Iron Mountain (unpublished data, AF543496). The phylogenetic analysis, does not relate the clone sequences to any representative of the subdivision. The closest relative is Desulfosarcina variabilis, a sulfate-reducing bacteria.
The sequences representing the second most abundant type ( $22 \%$ of the clones) are firmly positioned in the Acidithiobacillus ferrooxidans group (Figure 4). These sequences represent $14 \%$ of the clones in October and $8 \%$ in January (Table 2). The sequences are distributed within three genomovars. Sequences S5Jan27 and S5Oct27 are found in the genomovar II, having more than $99 \%$ similarity with the sequence of $\mathrm{A}$. ferrooxidans strain SS6, isolated in an uranium mining waste pile (Selenska-Pobell et al. 2001). Sequence S5Oct75 falls in the genomovar IV, showing 99\% similarity with the sequence of the clone RA13C4, found in monochlorobenzene contaminated groundwater (Alfreider et al. 2002). Sequence S5Jan20 belongs to the genomovar I having $99 \%$ similarity with A. ferrooxidans KF/GS-JG36-22 isolated in uranium mining waste piles (Selenska-Pobell et al. 2001).

The next most abundant sequence type, representing $12 \%$ of the clones in October, is positioned within the beta subdivision of the Proteobacteria (Table 2, Figure 5), having $>98 \%$ similarity to the sequence of the clone BVB20, obtained from a landfill leachate-polluted aquifer (Rölling et al. 2001). These 


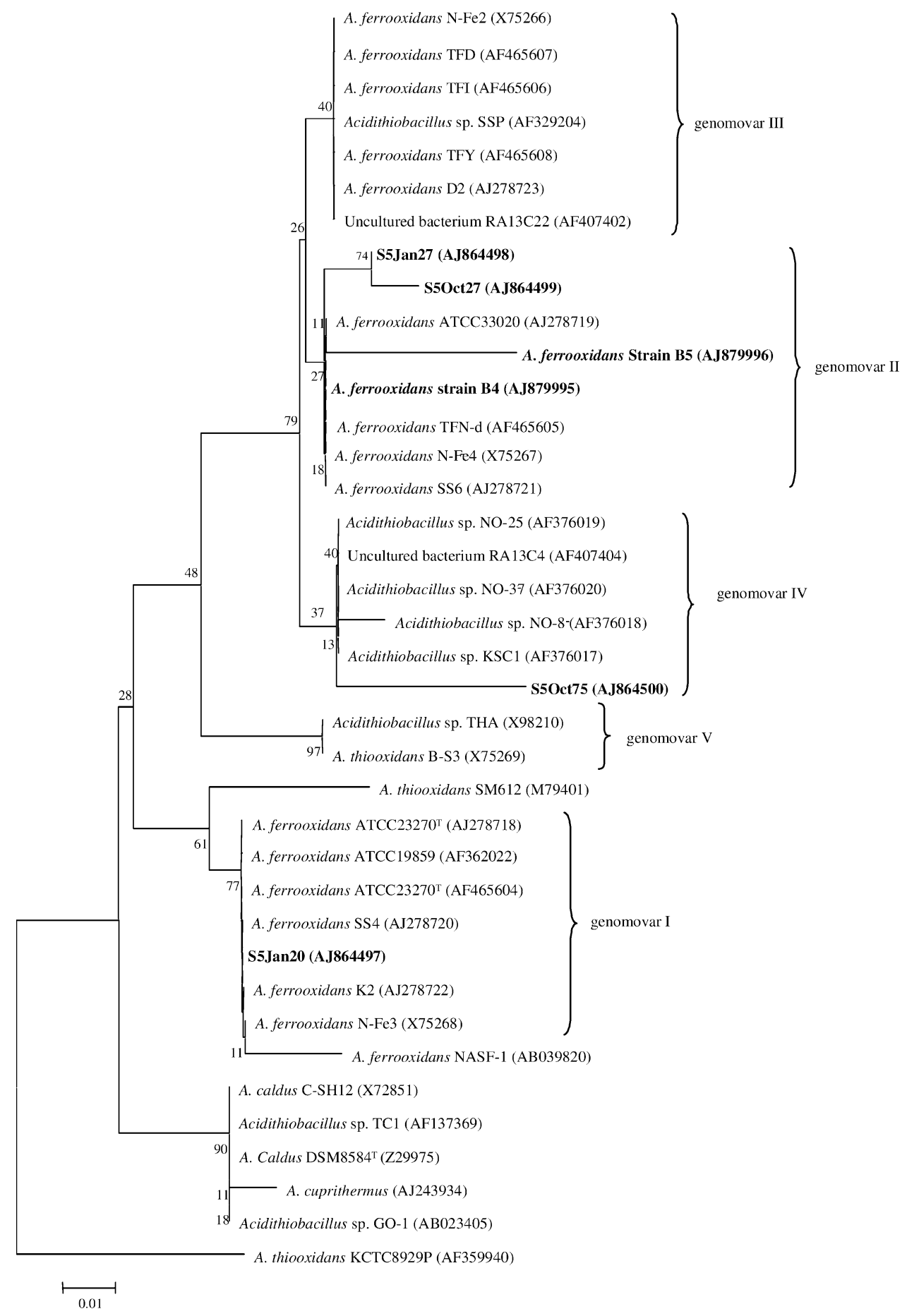

FIG. 4. Phylogenetic analysis of $16 \mathrm{~S}$ rRNA encoding gene sequences affiliated with the Acidithiobacillus division in tailings water at the Carnoulès mine (France). Clone names in bold correspond to sequences found in October (Oct) and January (Jan).

sequences are distantly related ( $>92 \%$ similarity) to the sequence of Thiobacillus sp.; therefore, the phylogenetic position within the group cannot be further resolved.

The other sequence type detected only in January, representing $8 \%$ of the clones, is affiliated with the Sulfobacillus group, with $>93 \%$ similarity with the Sulfobacillus sp. P35 strain, isolated from a pyrite-oxidizing bacterial population (Figure 6). Finally, the last sequence type clustering within the Actinobacteria group (Table 2) is the least abundant clone. The sequence is distantly related to sequences of environmental 


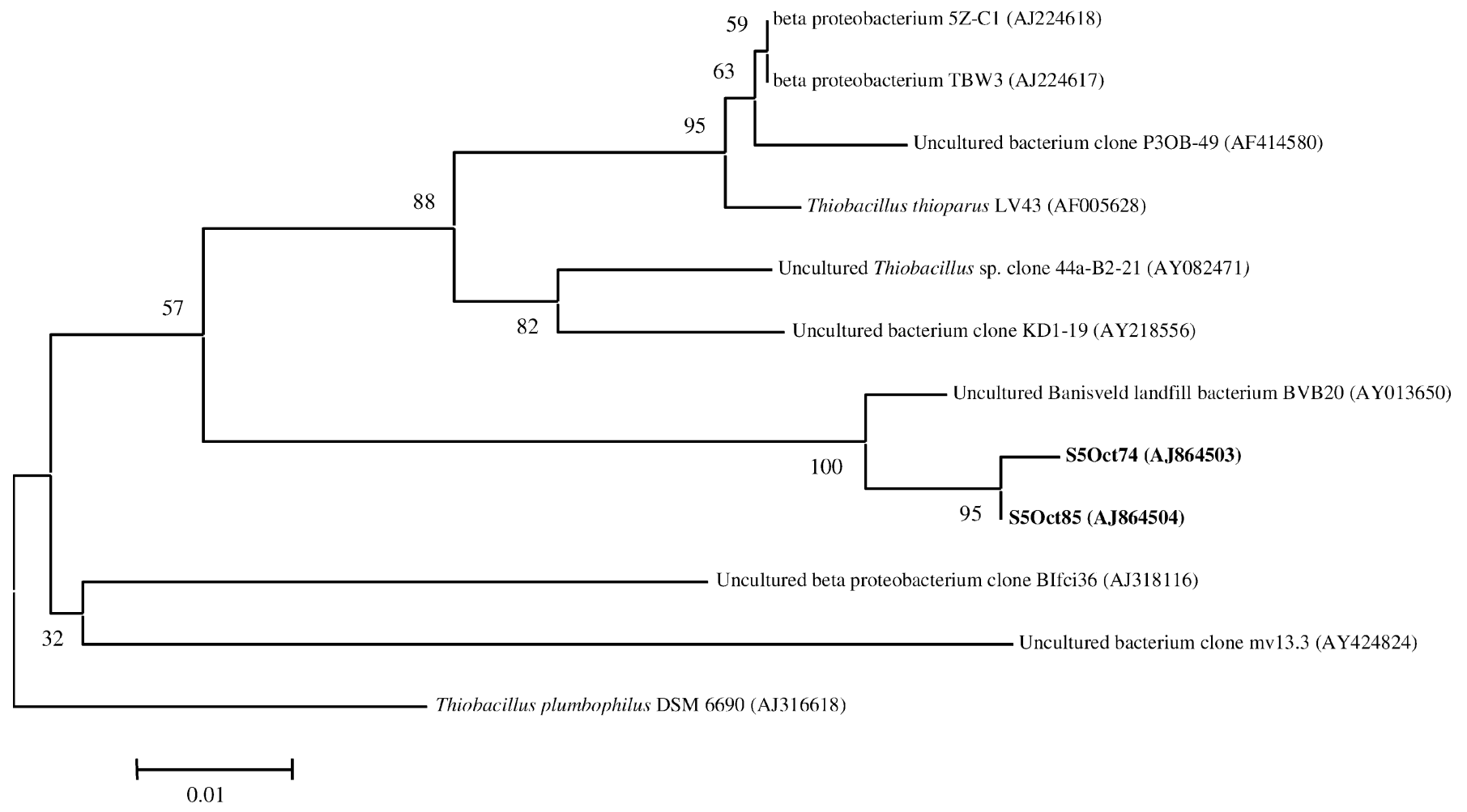

FIG. 5. Phylogenetic analysis of $16 \mathrm{~S}$ rRNA encoding gene sequences affiliated with the Thiobacillus division in tailings water at the Carnoulès mine (France). Clone names in bold correspond to sequences found in October (Oct) and January (Jan).

clones (92\%), especially to that of MC87 obtained from Iron Mountain (Stackebrandt et al. 1993) and related to Acidimicrobium (formely Actinomycete, (Stackebrandt et al. 1997)).

\section{Bacterial Isolation, Enumeration, and Identification}

The total number of bacteria, ranged from 6 to $7 \log \mathrm{FU}$ (Fluorescence Units per milliliters) (Figure 7). The solid R2A and 100:10 media result in the growth of only two groups of bacteria belonging respectively to the genus Thiomonas and to the species Acidithiobacillus ferrooxidans (Bruneel et al. 2003; Morin et al. 2003). For the A. ferrooxidans group, two strains were isolated, B4 and B5 but these strains are not detected in the 16S rRNA encoding gene libraries (Figure 4). The number of Thiomonas and Acidithiobacillus ferrooxidans ranged respectively from 1 to $4 \operatorname{logs} \mathrm{CFU} \cdot \mathrm{ml}^{-1}$ and from 0 to 3 $\operatorname{logs} \mathrm{CFU} \cdot \mathrm{ml}^{-1}$, representing only $0.1 \%$ of the total bacteria (Figure 7). The evolution of these two groups exhibits strong variation. The group of Thiomonas is always present, whereas A. ferrooxidans is absent in April and May during the period of high water level. The number of Thiomonas increases with the $\mathrm{pH}$ (Figure 7), reflecting a neutrophilic capability of growth. It always exceeds the number of $A$. ferrooxidans, excepted in December and January during the low $\mathrm{pH}$ period.

\section{DISCUSSION}

The results show the predominance of only three populations representing about $70 \%$ of the populations whatever the sam- pling date. This low bacterial diversity revealed by molecularbased methods is probably due to the small number of metabolically beneficial reactions available in AMD generated by pyrite oxidation as previously reported (Baker and Banfield 2003). In this kind of water, the number of available electron donors and acceptors is restricted, shaping the microbial ecology.

Most of the clone sequences (up to 90\%) although related to sequences already found in AMD, can not be closely related to cultured organisms, suggesting that they may constitute new taxa. Only clones from Acidithiobacillus ferrooxidans can be closely related to cultured organisms. However, although bacterial strains have not been isolated, it is possible to predict their physiological role, as it has been demonstrated that phylogenetically-related microorganisms share metabolic and physiological characteristics (Bond et al. 2000).

The dominant bacterial populations are related to the delta subdivision of the Proteobacteria, with closest affiliation to the sulfate-reducing bacteria Desulfosarcina variabilis. This population is found during both seasons. The anaerobic respiration is the dominant physiological trait of this group. In this respect, the occurrence of this bacterial population, observed in January, where the water is saturated with regards to oxygen may be surprising. However, this is in agreement with several recent studies indicating the presence of SRB and iron-reducing bacteria in the sediment of mining lakes and in mine tailings, even under oxic and acidic conditions where they participate to Fe and S cycling (Friese et al. 1998; Fortin et al. 2000). SRB have also 


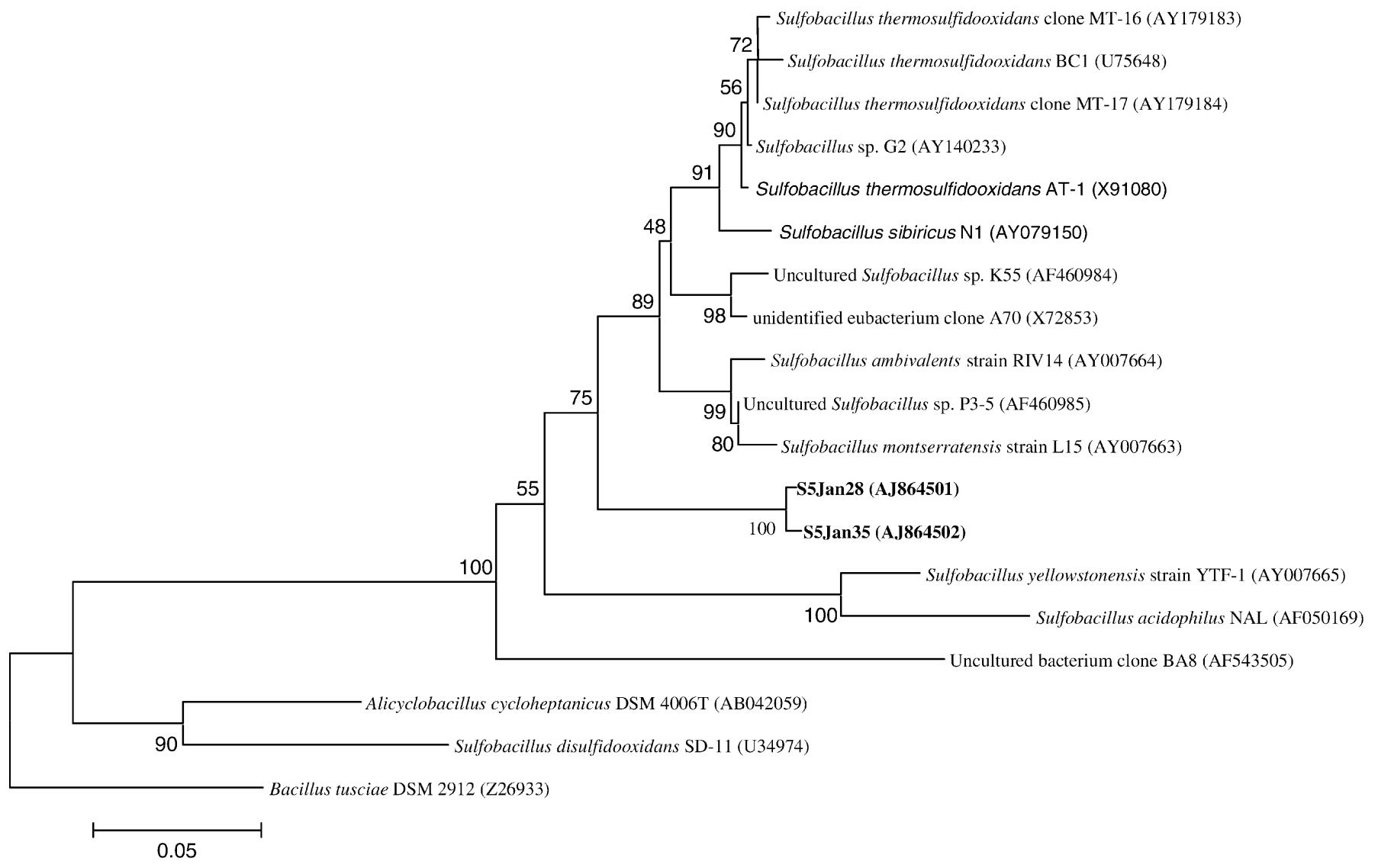

FIG. 6. Phylogenetic analysis of $16 \mathrm{~S}$ rRNA encoding gene sequences affiliated with the Sulfobacillus division in tailings water at the Carnoulès mine (France). Clone names in bold correspond to sequences found in October (Oct) and January (Jan).

been reported in marine oxic sediment layers (Wieringa et al. 2000). In the Carnoulès tailing, the phylogenetic analysis reveals that clone sequences of $D$. variabilis are distributed in two clusters (Figure 3), group I (October) and group II (January), suggesting possible differences in their physiology according to the availability of oxygen. Since it is surprising that sulfate and iron reduction occurs at such $\mathrm{O}_{2}$ concentrations it would be necessary to elucidate precisely the ecophysiological function of these bacteria. For this purpose it is needed to isolate them by using specific media and culture conditions.

Clones that could be related to oxidizing bacteria (sulfide and/or metals) are found in both seasons. A. ferrooxidans was also found in the two sampling period. In October, the oxidizing bacteria are positioned in the $\beta$ subdivision of the Proteobacteria closely related to the Thiobacillus group, whereas in January they are related to the gram positive Sulfobacillus species belonging to the Firmicutes group. Isolates of Sulfobacillus spp. are chemolithotrophs that can use reduced sulfur or iron compounds as energy source; they show mixotrophic and autotrophic growth (Golovacheva and Karavaiko 1978). These bacteria oxidize ferrous iron or reduce ferric iron, according to their metabolic activity related to the availability of DO (Bridge and Johnson 1998).
According to these authors, these iron-reducing bacteria accelerate the reductive dissolution of ferric iron-containing minerals such as jarosite and goethite. Clones falling within Actinobacteria group can also be related to iron-oxidizing, heterotrophic, acidophilic bacteria capable of autotrophic growth, such as Acidimicrobium. Species of heterotrophic and

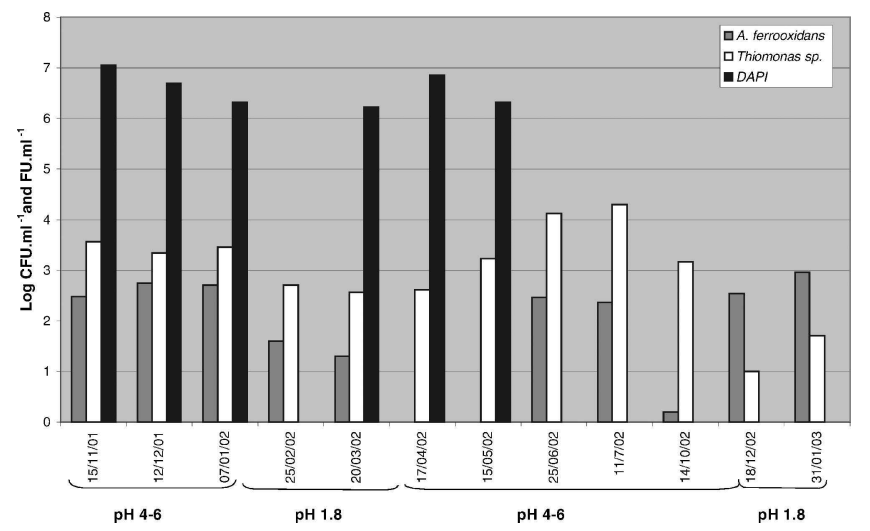

FIG. 7. Changes in Thiomonas sp. and A. ferrooxidans populations (CFU on solid media) and total number of bacteria (FU after DAPI staining) in Carnoulès tailings stock over a one-year period. 
autotrophic oxidizing bacteria have been found to coexist in AMD, where they are suspected to play a synergistic role in removing organic carbon and reduced metal forms (Bond et al. 2000). Thiomonas which has been isolated and shown to be very active on the oxidation of As (Bruneel et al. 2003) could not be detected using molecular techniques reflecting probably their low abundance.

In conclusion, the seasonal variations of chemical parameters in the Carnoulès AMD system influence the bacterial community structure. In January, when DO is high and pH low, the system is running with populations related to $D$. variabilis group II, A. ferrooxidans genomovar I and II, and populations related to Sulfobacillus. In October, when DO is low and $\mathrm{pH}$ high, the system involves $D$. variabilis group I, populations related to A. ferrooxidans genomovar II, Thiobacillus and Acidimicrobium. However, is it noteworthy that D. variabilis and A. ferrooxidans are present whatever the physicochemical conditions. Thus, it appears that microorganisms are adapted to suit specific physical and chemical conditions conferring to the bacterial communities present in Carnoulès AMD the ability to maintain the system over the seasonal variations.

\section{REFERENCES}

Alfreider A, Vogt C, Babel W. 2002. Microbial diversity in an in situ reactor system treating monochlorobenzene contaminated groundwater as revealed by 16 S ribosomal DNA analysis. Syst Appl Microbiol 25:232-240.

Altschul SF, Gish W, Miller W, Myers EW, Lipman DJ. 1990. Basic local alignment search tool. J Mol Biol 215:403-410.

Baker BJ, Banfield JF. 2003. Microbial communities in acid mine drainage. FEMS Microbiol Ecol 44:139-152.

Baneyx F. 1999. Recombinant protein expression in Escherichia coli. Curr Opin Biotechnol 10:411-421.

Bond PL, Smriga SP, Banfield JF. 2000. Phylogeny of microorganisms populating a thick, subaerial, predominantly lithotrophic biofilm at an extreme acid mine drainage site. Appl Environ Microbiol 66:3842-3849.

Bridge TAM, Johnson DB. 1998. Reduction of soluble iron and reductive dissolution of ferric iron-containing minerals by moderately thermophilic ironoxidizing bacteria. Appl Environ Microbiol 64:2181-2186.

Bruneel O, Personné J-C, Casiot C, Leblanc M, Elbaz-Poulichet F, Mahler BJ, Le Flèche A, Grimont PAD. 2003. Mediation of arsenic oxidation by Thiomonas sp. in acid mine drainage (Carnoulès, France). J Appl Microbiol 95:492-499.

Casiot C, Leblanc M, Bruneel O, Personné, J-C, Koffi K, Elbaz-Poulichet F. 2003. Geochemical processes controlling the formation of As-rich waters within a tailings impoundment. Aquat Geochem 9:273-290.

Edwards KJ, Goebel BM, Rodgers TM, Schrenk MO, Gihring TM, Cardona MM, Hu B, McGuire MM, Hamers RJ, Pace NR, Banfield JF. 1999. Geomicrobiology of pyrite $\left(\mathrm{FeS}_{2}\right)$ dissolution: case study at Iron Mountain, California. Geomicrobiol J 16:155-179.

Felsenstein J. 1993. PHYLIP-Phylogeny Inference Package (version 3.5c), Department of Genetics, University of Washington, Seattle, WA.
Fortin D, Roy M, Rioux JP, Thibault PJ. 2000. Occurrence of sulfate-reducing bacteria under a wide-range of physico-chemical conditions in $\mathrm{Au}$ and $\mathrm{Cu}-\mathrm{Zn}$ mine tailings. FEMS Microbiol Ecol 33:197-208.

Friese K, Wendt-Potthoff K, Zachmann DW, Fauville A, Mayer B, Veizer J. 1998. Biogeochemistry of Iron and Sulfur in sediments of an acidic mining lake in Lusatia, Germany. Water Air Soil Pollut 108:231-247.

Golovacheva RS, Karavaiko GI. 1978. New genus of thermophilic spore-forming bacteria, Sulfobacillus. Microbiology 47:658-665

Johnson DB, Hallberg KB. 2003. The microbiology of acidic mine waters. Res Microbiol 154:466-473.

Kelly DP, Wood AP. 2000. Reclassification of some species of Thiobacillus to the newly designated genera Acidithiobacillus gen. nov., Halothiobacillus gen. nov., and Thermithiobacillus gen. nov. Int J Syst Bacteriol 50:511-516.

Koffi K, Leblanc M, Jourde H, Casiot C, Pistre S, Gouze P, Elbaz-Poulichet, F. 2003. Reverse oxidation zoning in mine tailings generating arsenic-rich acidic waters (Carnoulès, France). Mine Water Environ 22:7-14.

Lane DJ. 1991. rRNA sequencing. In: Stachenbradt GME. editor. Nucleic Acid Techniques in Bacterial Systematics., Wiley, Chichester: Wiley. p 115-175.

Langmuir D. 1997. Acid mine waters. In: McConnin R, editor, Aqueous Environmental Geochemistry. Englewood Criffs, NJ: Prentice-Hall. p 457-478.

Leblanc M, Casiot C, Elbaz-Poulichet F, Personné J Ch. 2002. Arsenic removal by oxidising bacteria in an heavily arsenic contaminated acid mine drainage system (Carnoulès, France). In: Younger PL, Robins NS, editors. Mine Water Hydrogeology and Geochemistry. London: Geological Society. p 267-274.

Morin G, Juillot F, Casiot C, Bruneel O, Personné J-C, Elbaz-Poulichet F, Leblanc M, Ildefonse P, Calas G. 2003. Bacterial formation of tooeleite and mixed arsenic(III) or arsenic(V)-Iron(III) gels in the Carnoulès acid mine drainage, France. A XANES, XRD, and SEM study. Environ Sci Technol 37:1705-1712.

Rölling WFM, van Breukelen BM, Braster M, Lin B, van Verseveld HW. 2001. Relationships between microbial community structure and hydrochemistry in a landfill leachate-polluted aquifer. Appl Environ Microbiol 67:4619-4629.

Schrader JA, Holmes DS. 1988. Phenotypic switching of Thiobacillus ferrooxidans. J Bacteriol 170:3915-3923.

Selenska-Pobell S, Kampf G, Flemming K, Radeva G, Satchanska G. 2001. Bacterial diversity in soil samples from two uranium waste piles as determined by rep-APD, RISA and 16S rDNA retrieval. Anton Leew 79:149-161.

Silverman MP, Ehrlich HL. 1964. Microbial formation and degradation of minerals. In: Umbreit WW, editor. Advances in Applied Microbiology, New York: Academic Press. p 153-206.

Stackebrandt E, Liesack W, Goebel BM. 1993. Bacterial diversity in a soil sample from a subtropical Australian environment as determined by $16 \mathrm{~S}$ rDNA analysis. FASEB J 7:232-236.

Stackebrandt E, Rainey FA, Ward-Rainey NL. 1997. Proposal for a new hierarchic classification system, Actinobacteria classis nov. Int J Syst Bacteriol 47:479-491.

Thompson JD, Higgins DG, Gibson TJ. 1994. CLUSTAL W: improving the sensitivity of progressive multiple sequence alignment through sequence weighting, position-specific gap penalties and weight matrix choice. Nucleic Acids Res 22:4673-4680.

Weisburg WG, Barns SM, Pelletier DA, Lane DJ. 1991. 16S ribosomal DNA amplification for phylogenetic study. J Bacteriol 173:697-703.

Wieringa EBA, Overmann J, Cypionka H. 2000. Detection of abundant sulphatereducing bacteria in marine oxic sediment layers by a combined cultivation and molecular approach. Environ Microbiol 2:417-427. 